\title{
Phytochemical evaluation and comparative antibiocide efficacy of Aqueous, Ethanolic and equal mixture of aqueous and ethanolic (1:1) bark extract of Lannea coromandelica L. procured from Eastern region of India
}

\author{
Kuntal Das \\ Department of Pharmacognosy and Phytochemistry, Krupanidhi College of Pharmacy, \\ \#12/1, Carmelaram Post, Varthur Hobli. Bangalore - 35, India \\ Mob: +919632542846 \\ E-mail address: drkkdsd@gmail.com
}

\begin{abstract}
The present investigation was evaluating the potential antibacterial activity of three different extracts of the bark of Lannea coromandelica Linn. (LC) tree procured from Eastern India. Extraction of bark separation was carried out using aqueous, ethanol and a mixture of aqueous and ethanol. Microbiocides of all the extracts were separately evaluated against several microorganisms viz. Bacillus substilis, Staphylococcus aureus, Streptococcus pyogenes, Pseudomonus aeruginosa, Escherichia coli and Serratia marcescens by agar diffusion technique. The Minimum Inhibition Concentration (MIC) of all the extracts was carried out by the serial dilution method. The results of MIC ranged from 12.5 to $150 \mathrm{mg} / \mathrm{ml}$ (all the three extracts). The concentration dependent $\left({ }^{* *} \mathrm{P}<0.01\right.$ ) potential antimicrobial activity was resulted and at the dose of $200 \mathrm{mg} / \mathrm{ml}$, combined aqueous and ethanol extract of LC (LCAE + LCEE) gave significant results against gram positive bacteria where the maximum zone of inhibition was recorded against Streptococcus pyogenes $\left(17.0 \pm 0.05^{* *}\right)$ followed by Straphyloccus aureus (13.6 $\left.\pm 0.05^{* *}\right)$. Further, the same extract showed the maximum relative percentage inhibition against Straphyloccus aureus (178.64\%) followed by Streptococcus pyogenes $(143.42 \%)$. Such variation may be due to the effects of choice of solvent and the quantity of the extracted amount and also the geographical source of the plant part. These results represent scientific evidence to support the traditional medicinal uses of LC bark extracts and indicate a promising potential used against the treatment of infectious diseases caused by pathogenic bacteria and also provide scientific evidence for their efficacy to prepare the alternate newer medicine for antibiotics.
\end{abstract}

Keywords: Antimicrobial study; agar diffusion technique; extracts; Lannea coromandelica; MIC; relative percentage inhibition 


\section{INTRODUCTION}

Nature is created by God. All the diseases and their remedies are present in nature but we have to identify the particular things to cure the diseases. It is believed that natural sources have provided an array of natural drugs for the treatment of various infectious diseases. Plants are much more exploited as traditional natural sources for the treatment of various diseases. India is an herbal hub where plants are used for curing of various diseases traditionally and further documented by researchers with their various methods.

Hence, these evidences are the future pathway for the plant based data which are used in recent era for the development of various formularies and their preclinical and clinical study that revealed the development of drug design by providing a major focus in global health complications. The medicinal value of plants, mainly depends on the secondary metabolites that are procured from the various parts of the plants which produce a significant physiological action on the human health.

The most important bioactive compounds of plants are alkaloids, flavonoids, tannins and phenolic compounds (Dhiman and Lal, 2011). Hence all the plants in different locations around the world have been extracted, purified to investigate their individual activities (Varahalarao and Chandrashekar, 2010). The use of a wide range of antibiotics and various factors has led to the emergence of multidrug resistance to human pathogenic infections by bacterial strains (Berkowitz, 1995) because microbes involve in the change of their metabolism and genetic structure to acquire resistant against the drugs used in the treatment of infectious disease but antibiotics are scarce, costly and not affordable for all and therefore make compliance difficult.

So, to overcome microbial drug resistant, researchers are looking forward for the development of plant based novel drug molecules (Raghunath, 2008; Kumar et al., 2010). Plants are reported to have multi medicinal and pharmacological activities like antimicrobial, anticancer, antiinflammatory, antidiabetic, antioxidant, anti diuretic etc. and all these effects have been reported due to presence of mainly tannins and flavonoids (Hadia et al., 2012; Irudayaraj et al., 2012).

Of late, Lannea coromandelica (LC) Linn (Family: Anacardiaceae) is such deciduous tree which is abundantly distributed throughout tropical countries. In India the plant is seen in the roadside of Andhra Pradesh, Kerala, West Bengal and other states. Traditionally the bark is useful in treating cuts, wounds, bruises, ulcers, gastritis, enteritis, leukorrhagia, ophthalmia, gout, ulcerative stomatitis, odontalgia, sprains, diarrhea and dysentery (Jain and Tarafder, 1970). The leaves are used as antiinflammatory, neuralgia, and to treat sprains (Islam and Tahara, 2000; Gan et al., 2007).

However, recent research evidences revealed some of the acclaimed properties like the hypotensive (Islam et al., 2002), anti-inflammatory (Singh and Singh, 2005), cytotoxic effects (Rahman et al., 2008), analgesic and antioxidant activity (Badrul et al., 2012) of LC stem bark extract. In vitro antimicrobial study has also revealed with the ethanolic bark extract, but the result showed less effect that due to the geographical location of the plant (Kaur et al., 2013) furthermore it is well known that any pharmacological activity mainly depends on the active constituents present in the plant.

Hence the percentage of the same are varied with the location and other climatic factors, therefore the present study was undertaken to evaluate antimicrobial study of the three different bark extracts of LC on selected bacterial strains. 


\section{MATERIALS AND METHODS}

\section{1. Collection of Plant material}

The plant bark material was collected in the month of August -September, 2012 from Botanical garden of Kolkata, West Bengal, India. The plant has been identified and authenticated by Dr. T. N. Shivananda, Senior Scientist, Indian Institute of Horticultural Research, Bangalore, India, Department of Medicinal and Aromatic Plant. The bark of the plant along with leaf specimens were submitted to the Department of Pharmacognosy and Phytochemistry as herbarium with voucher specimen no 211/ Pharmacog/ Srinivasa/07.

\section{2. Preparation of Extracts}

The bark was shade dried for a month and coarse powder, prepared with hammer mill and stored at room temperature in a sealed plastic cover to avoid moisture absorption. Separately about $500 \mathrm{~g}$ of the powdered bark was extracted with aqueous, $80 \%$ ethanol and with the mixture of equal ratio of aqueous and ethanol solvent (1:1) by the hot maceration method as described by earlier (Srinivasa Rao et al., 2014). All the extracts were filtered separately, evaporated with the rotary flash evaporator at $35^{\circ} \mathrm{C}$ and stored in refrigerator for the proposed investigation. The yields of extracts were calculated.

\subsection{Phytochemical Screening}

The freshly prepared crude bark extracts viz aqueous (LCAE), ethanolic (LCEE) and a mixture of aqueous and ethanolic extracts of Lannea coromandelica (LCAE + LCEE) were qualitatively tested as described by Krishnaiah et al., 2009 for the presence of various phytoconstituents.

\section{4. Microorganisms Used}

The bacterial strains used were obtained from the stock culture of the department of Microbiology, Bangalore University, Bangalore, India. Few of the strains viz. Bacillus substilis ATCC 6633, Straphyloccus aureus ATCC 29737, Streptococcus pyogenes ATCC 13813, Pseudomonus aeruginosa ATCC 25619, Escherichia coli ATCC 8739 and Serratia marcescens ATCC 13880 were used for the present study, were grown and maintained in the nutrient agar medium in Dept. of Pharmaceutical microbiology, St. John's Pharmacy College, Bangalore.

Stock solution of broad-spectrum antibiotic (Ampicillin as a standard) was prepared as $30 \mathrm{mcg} / \mathrm{ml}(\mathrm{w} / \mathrm{v})$ concentration in sterile distilled water. The concentration of $0.1 \mathrm{ml}$ Ampicillin was used for the antibacterial assay in this experiment.

\section{5. Determination of minimum inhibitory concentration (MIC)}

Serial dilution method was used to measure MIC. Colony made from 24 hour culture of bacterium inoculated to Muller Hinton culture medium. $1.0 \mathrm{ml}$ of the extract solution at concentrations of $200 \mathrm{mg} / \mathrm{ml}$ was added to $1 \mathrm{ml}$ of nutrient broth to obtain extract concentrations of $150,100,50,25$ and $12.5 \mathrm{mg} / \mathrm{ml}$. A $0.1 \mathrm{ml}$ of each concentration was added to each $8 \mathrm{ml}$ of nutrient broth containing $0.1 \mathrm{ml}$ of the standardized test organism of bacterial cells and $0.5 \mathrm{McF}$ arland turbidity standard $\left(1.0 \times 10^{8} \mathrm{cfu} / \mathrm{ml}\right)$ was inoculated in each test tube and was mixed thoroughly in a vortex mixer. The tubes were then incubated at $37^{\circ} \mathrm{C}$ for $24 \mathrm{~h}$ (Rios et al., 1988). After incubation, the tube with lowest dilution with no detectable growth was considered the MIC. 


\section{6. Antibacterial Assay}

In vitro antibacterial activity of all the different extracts was assessed by the agar well diffusion method (Bauer et al., 1966). In this method, pure isolate of each microbe was sub cultured on the recommended specific media for each microorganism at $35-37^{\circ} \mathrm{C}$ for $25 \mathrm{~h}$. The agar plates were allowed to dry. The LCAE, LCEE and LCAE + LCEE extracts (100 mg) were dissolved separately in $1 \mathrm{ml}$ of (DMSO, Merck, Germany) and diluted to a final concentration of $200 \mathrm{mg} / \mathrm{ml}$; other concentrations were made $(50,100$ and $150 \mathrm{mg} / \mathrm{ml})$ by serial dilutions. The solutions were sterilized by filtration through a $0.45 \mu \mathrm{m}$ membrane filter. $6 \mathrm{~mm}$ discs were impregnated with sterile cork borer and $80 \mu \mathrm{l}$ of each extract were placed in the wells of agar plates inoculated with a microbial culture. Each extract was tested in triplicate. Ampicilin $(30 \mu \mathrm{g} / \mathrm{disc})$ served as a standard for the bacteria. For each extract three replications were made. After that the plates were incubated at $37^{\circ} \mathrm{C}$ for 24 hours and by next day an antibacterial activity was observed and recorded zone of inhibition ( $\mathrm{mm}$ ) by transparent scale.

\section{7. Determination of relative percentage inhibition}

The relative percentage inhibition of the test extracts with respect to standard and solvents (aqueous and ethanol) were calculated by using the following formula described by Ajay et al., 2003.

Relative percentage inhibition of the test extract $=100 \mathrm{X}(\mathrm{X}-\mathrm{Y}) /(\mathrm{Z}-\mathrm{Y})$

where,

$\mathrm{X}=$ total area of inhibition of the test extract

$\mathrm{Y}=$ total area of inhibition of the solvent

$\mathrm{Z}=$ total area of inhibition of the standard drug

The total area of the inhibition was calculated by using area $=\pi r^{2}$; where, $r=$ radius of the zone of inhibition

\section{8. Statistical analysis}

The experimental results were triplicated and zone of inhibition were determined in $\mathrm{mm}$. All the results were statistically expressed as the mean \pm standard error of mean (SEM). Values of ${ }^{* *} \mathrm{P}<0.01$ and ${ }^{*} \mathrm{P}<0.05$ were considered statistically significant. Graph Prism 5 software has used for the present study.

\section{RESULTS}

\section{1. Yield of extracts}

The percentage yields of different extracts of LC were at $4.32 \%, 5.60 \%$ and $6.32 \% \mathrm{w} / \mathrm{w}$ respectively (LCAE, LCEE and LCAE + LCEE extracts).

\section{2. Phytochemical studies of the extracts}

Preliminary phytochemical investigations of different extracts of LC were investigated and revealed the presence of carbohydrates, alkaloids, saponins, cardiac glycosides, steroids, tannins and flavonoids. The colors of the extracts were wine red, dark red and deep red, respectively with the LCAE, LCEE and LCAE+LCEE. 


\section{3. Determination of minimal inhibitory concentration (MIC)}

The results demonstrated that the MIC of all the extracts that could inhibit strains of all microorganisms was ranged from 12.5 to $150 \mathrm{mg} / \mathrm{ml}$ (Figure 1). According to the result of the MIC value, further the antimicrobial activity was performed.

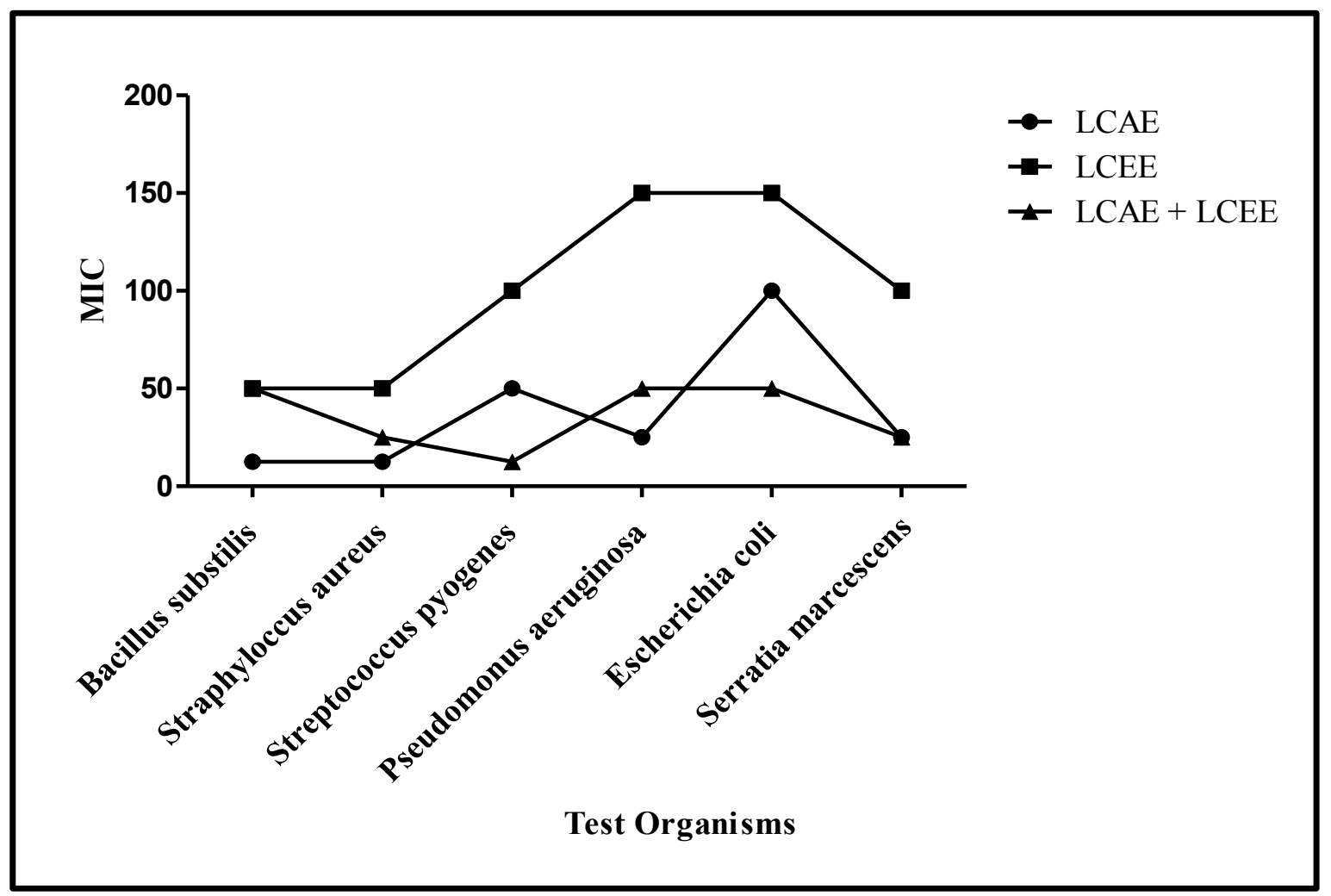

Figure 1. MIC against various microorganisms with all three extracts of LC.

LCAE = Aqueous extract of Lannea coromandelica $; \mathbf{L C E E}=$ Ethanolic extract of Lannea coromandelica $;$ LCAE + LCEE = Equal solvent mixture (1:1) of aqueous and ethanolic extract of Lannea coromandelica .

\section{4. Antibacterial Assay}

Antibacterial assay of all the three different extracts of LC was determined and resulted significant inhibition $(\mathrm{p}<0.05)$ with all the microorganisms with depending concentrations but are lesser than that of standard ampicillin. The LCAE exhibited the antibacterial activity against all the bacteria (Figure 2) and the results were expressed as mean \pm SEM $(n=3)$. Extract showed maximum antibacterial activity against Streptococcus pyogenes $\left(17.0 \pm 0.05^{*}\right)$ followed by Straphyloccus aureus $\left(13.6 \pm 0.05^{*}\right)$ and lowest activity against Serratia marcescens $\left(11.6 \pm 0.05^{*}\right)$ at the concentration of $200 \mathrm{mg} / \mathrm{ml}$. The bark extract of LCEE also revealed the same trend as earlier, as showed higher inhibition against Straphyloccus aureus $\left(17.47 \pm 0.03^{*}\right)$ followed by Streptococcus pyogenes $\left(14.42 \pm 0.02^{*}\right)$ and lowest activity against Serratia marcescens $\left(11.9 \pm 0.08^{*}\right)$ (Figure 3 ) whereas the combined equal mixture extract of LC (LCAE + LCEE) shown maximum activity of $19.73 \pm 0.07 *$ against Straphyloccus aureus and the lowest one with Serratia marcescens $\left(12.2 \pm 0.05^{*}\right)$ (Figure 4). Even in comparison to all the extracts combined solvent extract shows more significant results than other two extracts and more effective against gram positive bacteria than a gram negative bacteria. 


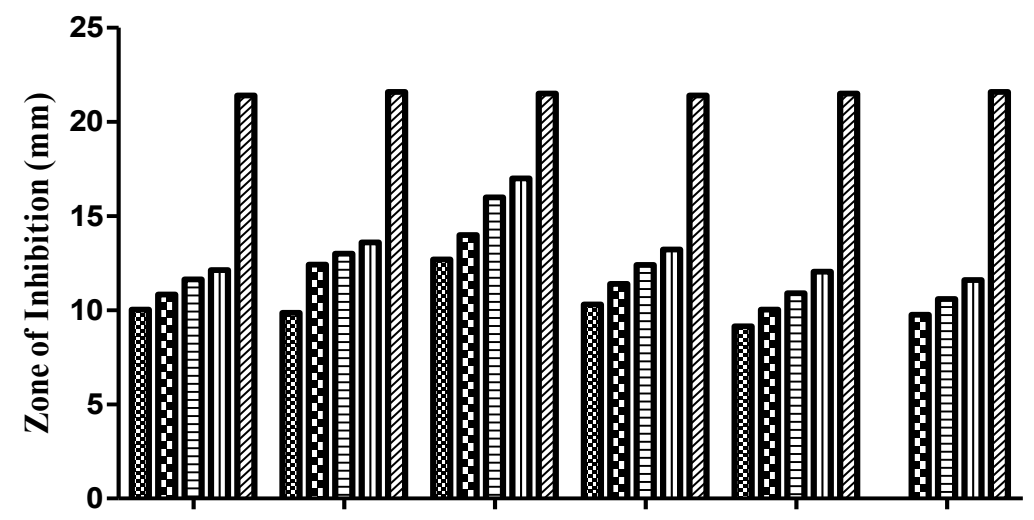

\%क LCAE $50 \mathrm{mg} / \mathrm{ml}$

Wr $100 \mathrm{mg} / \mathrm{ml}$

Ð $150 \mathrm{mg} / \mathrm{ml}$

سण $200 \mathrm{mg} / \mathrm{ml}$

(m) Standard

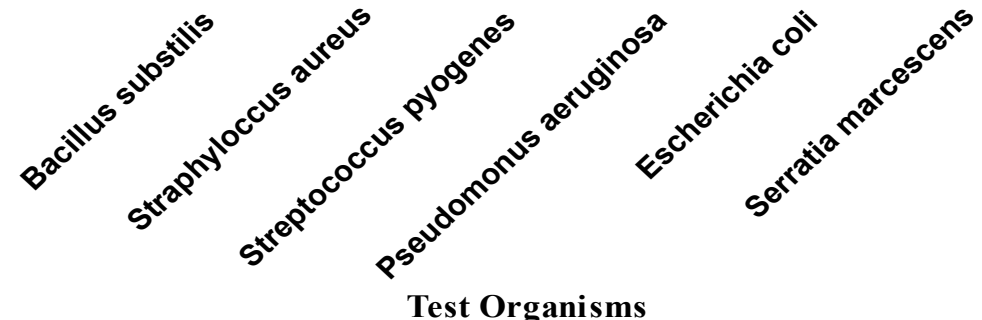

Figure 2. Antibacterial activity of LCAE against various organisms. LCAE = Aqueous extract of Lannea coromandelica .

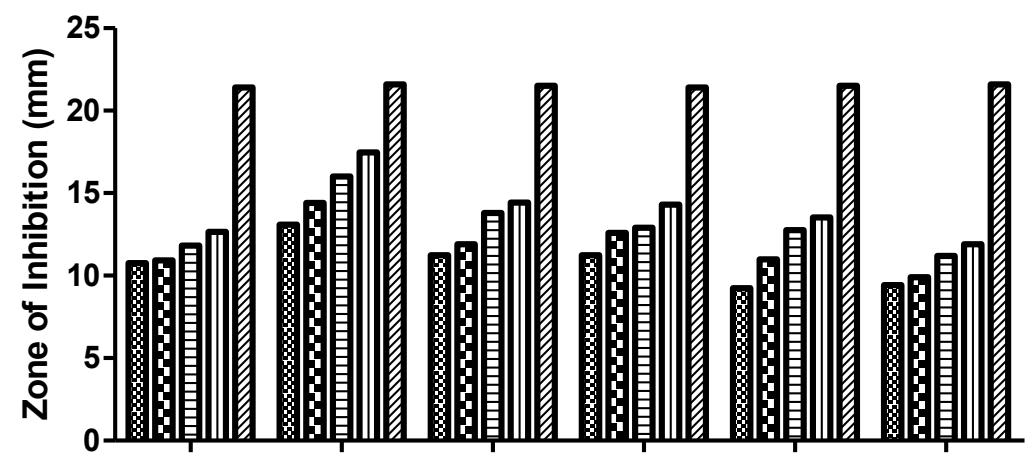

LCEE $50 \mathrm{mg} / \mathrm{ml}$

Ex $100 \mathrm{mg} / \mathrm{ml}$

Е $150 \mathrm{mg} / \mathrm{ml}$

III $200 \mathrm{mg} / \mathrm{ml}$

[Iת Standard

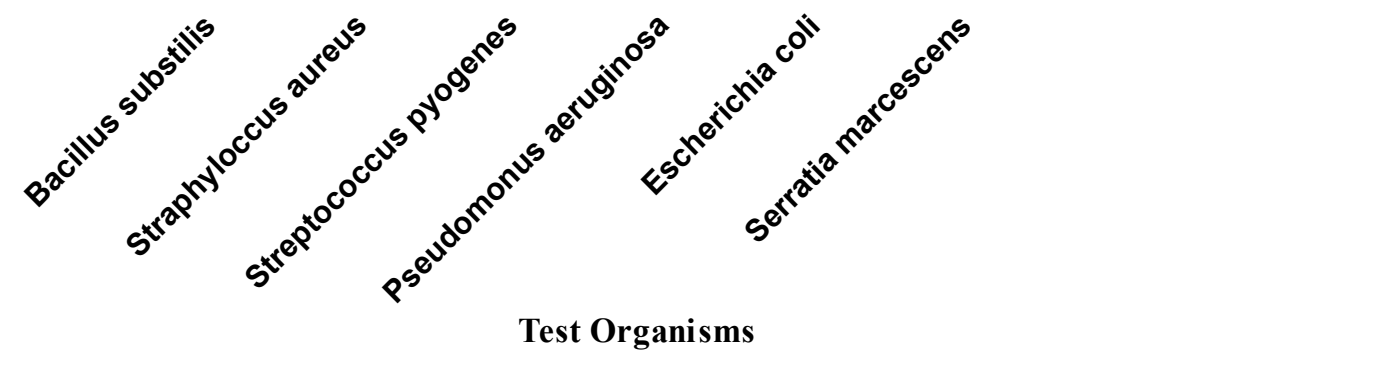

Figure 3. Antibacterial activity of LCEE against various organisms. LCEE $=$ Ethanolic extract of Lannea coromandelica . 


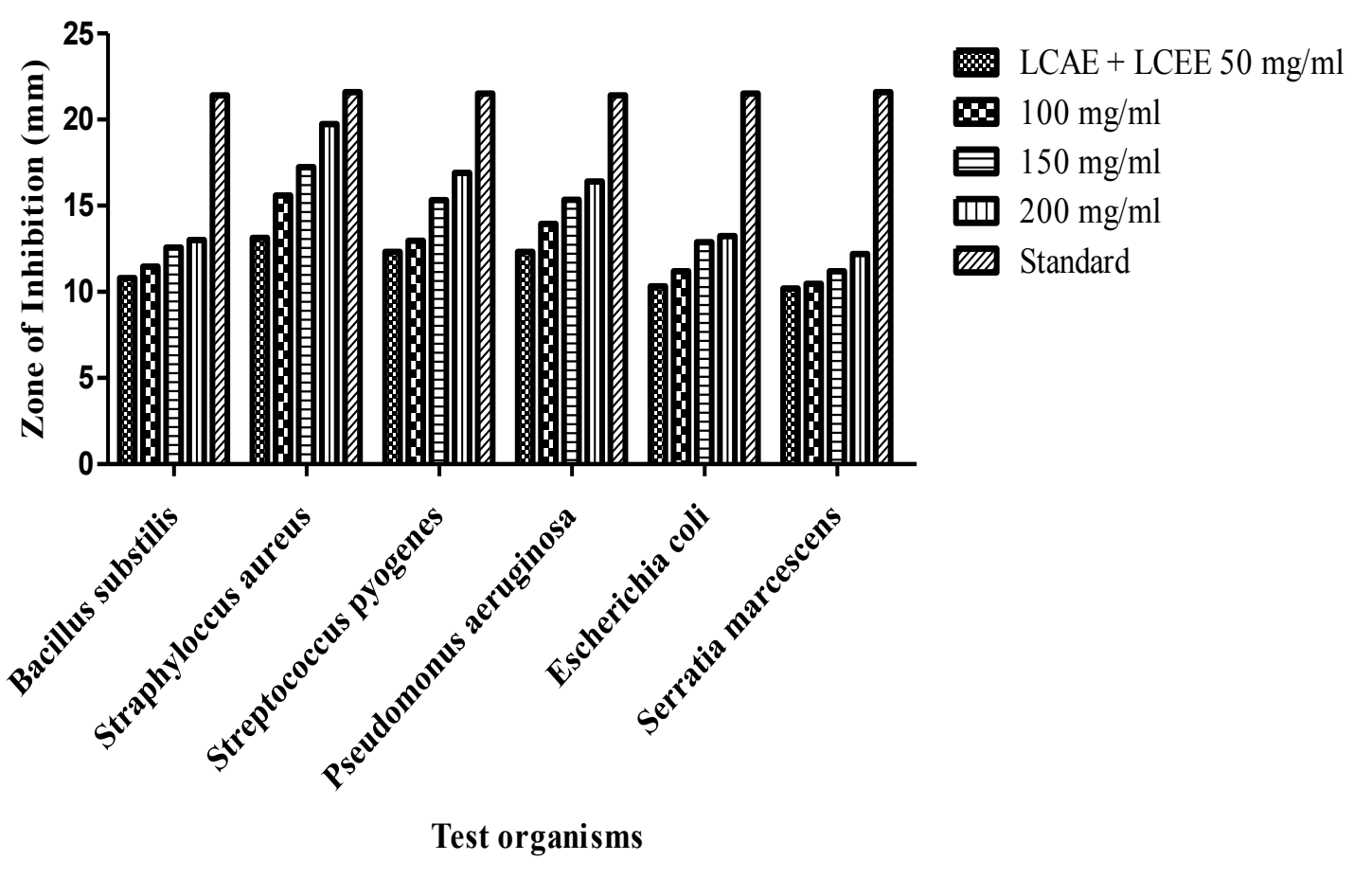

Figure 4. Antibacterial activity of LCAE + LCEE against various organisms.

LCAE + LCEE = Equal solvent mixture (1:1) of aqueous and ethanolic extract of Lannea coromandelica.

\section{5. Relative percentage inhibition}

The results of antimicrobial activity of all the extracts of LC were compared with a standard ampicilin for evaluating their relative percentage inhibition (Figure 5).

The result revealed the mixed extract of LCAE and LCEE exhibits maximum relative percentage inhibition against Straphyloccus aureus (178.64\%) followed by Streptococcus pyogenes (143.42\%), Bacillus substilis (112.43\%), Escherichia coli (90.57\%), Pseudomonus aeruginosa (79.68\%) and Serratia marcescens (58.04\%) respectively.

Whereas LCEE showed percentage inhibition lesser than former extract and the list percentage inhibition showed with the LCAE. 


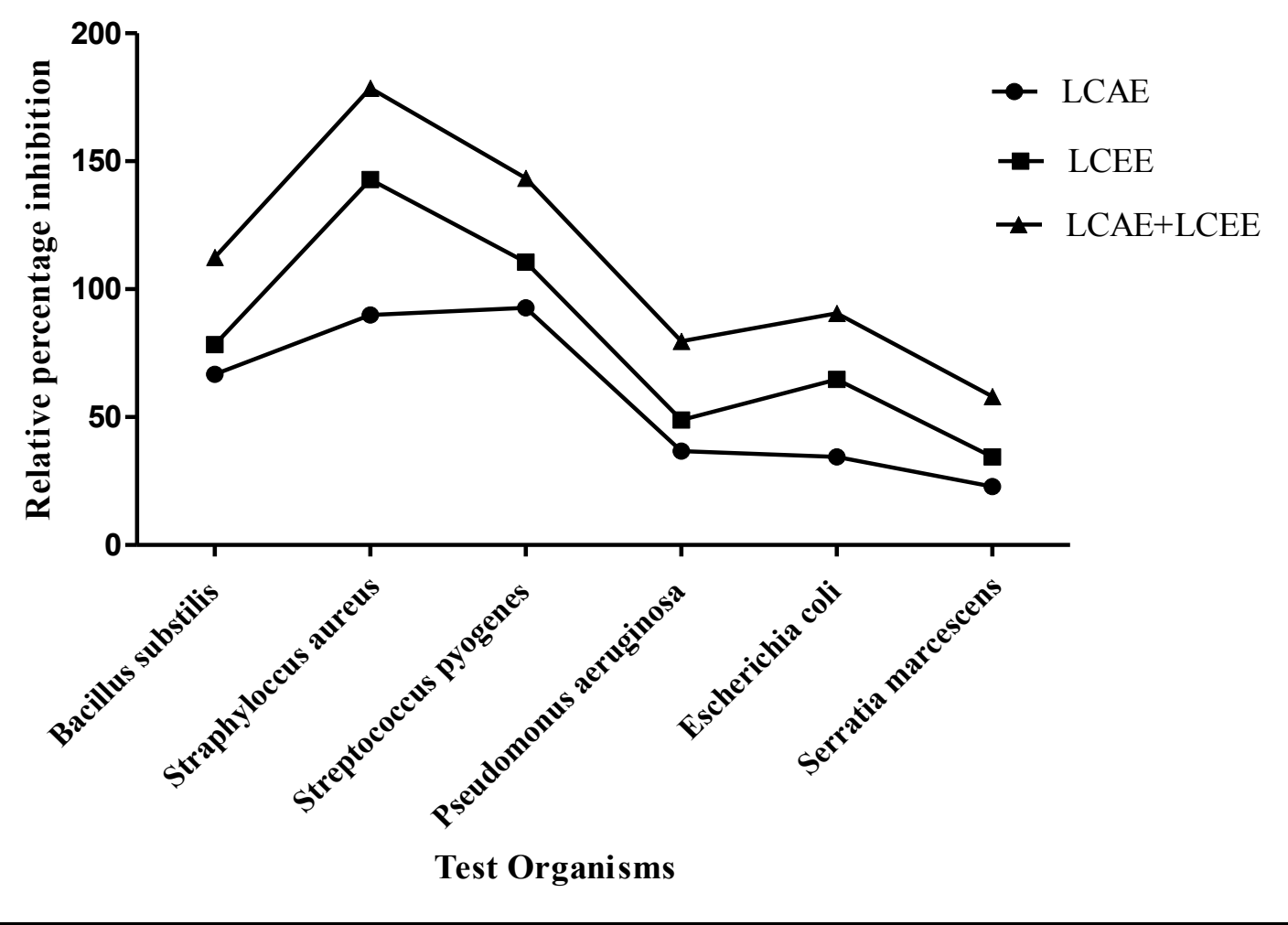

Figure 5. Relative percentage inhibition of LC extracts.

LCAE = Aqueous extract of Lannea coromandelica $; \mathbf{L C E E}=$ Ethanolic extract of Lannea coromandelica $;$ LCAE + LCEE = Equal solvent mixture (1:1) of aqueous and ethanolic extract of Lannea coromandelica.

\section{DISCUSSION}

Phytochemical derived from plant products are generally developed less toxic and effective medicines in controlling growth of microorganism. Further, antimicrobial activity of various plant parts has been reported by the many researchers but it is worthwhile to focus on the area where no literatures investigated the comparative antimicrobial activity of LC extracts collected from Eastern region of India. Keeping this, three different extracts viz LCAE, LCEE and combined LCAE and LCEE were prepared from the collected bark powder and susceptibility of each plant extract was tested by the serial microdilution method (MIC). Finally antimicrobial study was evaluated and antimicrobiosides were compared with standard ampicillin. The present investigations endow with the basic information regarding this plant bark with potent substantial antimicrobial activity against all the pathogens used in this present investigation. However, all the three extracts showed concentration dependent inhibitory effects on all the bacteria species.

This finding also correlated with the literatures earlier reported (Nkere and Lroegbu, 2005; Das et al., 2009) who independently found that various plant extracts inhibits the growth of some bacteria isolates. It was observed that the antimicrobial effect of the plant extract varies from one plant to another and this may be due to many factors viz. the effect of climate, soil composition, age of plant, quality, quantity, solvent used for extraction, extraction conditions, composition of extracting product and different bacterial strains (Masotti et al., 2003; Angioni et al., 2006; Bedi et al., 2010; Bakht et al., 2011). The present 
investigation was carried out with three different extracts including aqueous and alcohol and their mixture and revealed the most significant activity when the combined solvents were used for the extraction followed by alcohol and aqueous. The same trend was followed with the earlier literature reported by earlier (Basuri et al., 2011). Mainly secondary metabolites exert antimicrobial activity through different mechanisms where tannins have been found to form irreversible complexes with prolinerich protein (Shimada, 2006) resulting in the inhibition of cell protein synthesis of the bacterial cell. Whereas flavonoids are one of the constituent of stem bark extracts of various plant species that exhibited a wide range of biological activities like antimicrobial, anti-inflammatory, analgesic, anti-allergic and antioxidant properties (Hodek et al., 2002).

Earlier literature reported that the preliminary phytochemicals that are present in the LC are flavonoids, triterpinoids, phenols, tannins, coumarins etc. (Islam and Tahara, 2000; Krishnaiah et al., 2008) and the major active ingredients like flavonoids, phenolic compounds and some newer isolated compounds are responsible for antimicrobial activity of LC (Yun et al., 2014). Therefore, combination of ethanol and aqueous bark extract of LC showed maximum antibacterial activity by a measured zone of inhibition and revealed more active against Straphyloccus aureus followed by Streptococcus pyogenes followed by ethanolic extract, which showed the same trend but lesser than mixed extract as well as than standard. Furthermore, the higher yield with more quantity of the extract procured in the combined extract which also results significant antibacterial activity than others.

\section{CONCLUSION}

All the three different extracts showed a concentration dependent potential antimicrobial activity, but the activity was less than standard drug ampicillin. All the three extracted bark samples showed statistically significant $(\mathrm{P}<0.05)$ antimicrobial activity in separate experiments, but the concentration dependent higher activity shown by the combined equal mixture of ethanol and aqueous bark extract i.e. (LCAE + LCEE) followed by LCEE and LCAE. This further confirmed that the bark of LC is a potent antibacterial agent and could be proved in the future as potential antimicrobial agent as non antibiotics sources. Hence, details phytochemical investigations are necessary to isolate and characterize its active compounds.

\section{Acknowledgements}

Author is thankful to Dr. Medhini, Bangalore Univeristy for provided microbial strains for the present study. Further extended help to Mr. Srinivasa Rao and Mr. Obedulla, M. Pharm student, for provided plant materials and helped for preparation of subculture of the microorganisms.

\section{References}

[1] Dhiman A., Lal R., 2011. Phytochemical and pharmacological status of Datura fastuosa Linn. Int J Res Ayurveda Pharm 2(1), 145-150.

[2] Varahalarao V., Chandrashekar NK., 2010. In Vitro bioactivity of Indian medicinal plant Calotropis procera (Ait.). Journal of Global Pharma Technology 2(2), 43-45.

[3] Berkowitz FE., 1995. Antibiotic resistance in bacteria. South Med. J 88, 797-804. 
[4] Kumar G., Karthik L., Bhaskara Rao KV., 2010. Antibacterial activity of aqueous extract of Calotropis gigantea leaves - an in vitro study. International Journal of Pharmaceutical Sciences Review and Research 4(2), 141-144.

[5] Raghunath D., 2008. Emerging antibiotic resistance in bacteria with special reference to India. J Biosci 33 (2008) 593-603.

[6] Hadia G., Rubina N., Qaisrani MAK., Shazia H., Nabila Y., 2012. Antibacterial and antifungal activity of different extracts of Datura stramonium (branches and leaves sample). J Biotech Pharm Res 3(9), 141-148.

[7] Irudayaraj V., Janaky M., Johnson M., Selvan N., 2012. Preliminary phytochemical and antimicrobial studies on a spike-moss Selaginella inaequalifolia (hook. \& grev.) Spring. Asian Pac J Trop Med 3(12), 957-960.

[8] Jain SK., Tarafder CR., 1970. Medicinal plants-lore of the sandals-A revival of PO Bodding's work. Econ Bot 24, 241-278.

[9] Islam MT, Tahara S., 2000. Dihydroflavonols from Lannea coromandelica. Phytochemistry 54, 901-907.

[10] Gan BC., Li RT., Yang XQ., Du DL., 2007. Ethnobotany studies on medicinal plants used by Li nationality in Wuzhishan area of Hainan province. Chin J Ethnomed Ethnopharm 4, 194-198.

[11] Islam MT., Sakasai M., Tahara S., 2002. Zoosporicidal activity of polyflavonoid tannin identified in Lannea coromaldelica stem bark against phytopathogenic oomycete aphanomyces cochlioides. J Agric Food Chem 6(23), 6697-6703.

[12] Singh S., Singh GB., 2005. Antiinflammatory activity of Lannea coromaldelica bark extract in rat. Phytother Res 8, 311-318.

[13] Rahman MS., Begum B., Chowdhury R., Rahman KM., Rashid MA., 2008. Preliminary cytotoxicity screening of some medicinal plants of Bangladesh. Dhaka Univ J Pharm Sci 7(1), 47-52.

[14] Badrul A., Sarowar H., Razibul H., Julia R., Anwarul I., 2012. Antioxidant and analgesic activities of Lannea coromandelica Linn bark extract. International $J$ of Pharmacol 8(4), 224.

[15] Kaur R., Jaiswal ML., Jain V., 2013. Protective effect of Lannea coromandelica Houtt. Merrill. Against three common pathogens. J Ayurveda Integr Med 4, 224-228.

[16] Srinivasa Rao V., Einstein JW., Das K., 2014. Hepatoprotective and antioxidant activity of Lannea coromandelica Linn. on thioacetamide induced hepatotoxicity in rats. International Letters of Natural Sciences 3, 30-43.

[17] Krishnaiah D., Devi T., Bono A., Sarbatly R., 2009. Studies on phytochemical constituents of six Malaysian medicinal plants. Journal of Medicinal Plants Research $3(2), 67-72$.

[18] Rios JL., Recio MC., Vilar A., 1988. Screening methods for natural products with antimicrobial activity: A review of literature. Journal of Ethnopharmacology 23, 127149.

[19] Bauer AW., Kirby WM., Sheriss JC., Turck M., 1966 Antibiotic susceptibility testing by a standardized single disk method. Am J Clin Pathol 45, 493-496. 
[20] Ajay KK., Lokanatha RMK., Umesha KB., 2003. Evaluation of antibacterial activity of 3,5-dicyano-4,6-diaryl-4-ethoxycarbonyl-piperid-2-ones. Journal of Pharmaceutical and Biomedical Analysis 27, 837-840.

[21] Nkere CK., Lroegbu CU., 2005. Antimicrobial screening of the root, seed and stem bark extracts of Picralima nitida. Afr J Biotechnol 4, 522- 526.

[22] Das K., Dang R., Gupta N., 2009. Comparative antimicrobial potential of different extracts of leaves of Stevia rebaudiana Bert. Int J Nat Eng Sci 3 (1), 59-62.

[23] Masotti VF., Juteau JM., Bessiere Viano J., 2003. Seasonal and phonological variations of the essential oil from the narrow endemic species Artemisia molinieri and its biological activities. Journal of Agricultural and Food Chemistry 51, 7115-7121.

[24] Angioni A., Barra A., Coroneo V., Dessi S., Cabras P., 2006. Chemical composition, seasonal variability, and antifungal activity of Lavandula stoechas L. ssp. Stoechas essential oils from stem/ leaves and flowers. Journal of Agricultural and Food Chemistry 54, 4364-4370.

[25] Bedi N., Bedi PMS., Bodiwala HS., Singh IP., Bansal P., 2010. Scientific evaluation of an innovative herbal medicine for relief in respiratory disorders. Canadian journal of pure \& applied sciences 4(3), 1249-1255.

[26] Bakht J., Tayyab M., Ali H., Islam A., Shafi M., 2011. Effect of different solvent extracted sample of Allium sativum (Linn) on bacteria and fungi. African Journal of Biotechnology 10(31), 5910-5915.

[27] Basuri TS., Patil C., Dhal NK., 2011. In vitro evaluation of antimicrobial activity of crude ethanolic extract of Lannea coromandelica (Linn.). Journal of Pharmacy Research 4(4), 1246-1247.

[28] Shimada T., 2006. Salivary proteins as a defense against dietary tannins. J. Chem. Ecol 32(6), 1149-1163.

[29] Hodek P., Trefil P., Stiborova M., 2002. Flavonoids - Potent and versatile biologically active compounds interacting with cytochrome P450. Chemico-Biol. Intern 139(1), 1-21.

[30] Islam MT., Tahara S., 2000. Dihydroflavonols from Lannea coromandelica. Phytochemistry 54, 901-907.

[31] Krishnaiah PV., Ratnam KV., Venkata RR., 2008. Preliminary Phytochemical evaluation of certain anticancer crude drugs used by adivasis of rayalaseema region, Andhra Pradesh, India. Ethn Bot Leaflets 12, 693-697.

[32] Yun XJ., Shu HM., Chen GV., Ji MH., Ding JY., 2014. Chemical constituents from bark of Lannea coromandelica. Chinese Herbal Medicines 6(1), 65-69. 